(1) CrossMark

Cite this: Analyst, 2014, 139, 4733

Received 10th March 2014

Accepted 18th June 2014

DOI: 10.1039/c4an00463a

www.rsc.org/analyst

\title{
Towards single-cell LC-MS phosphoproteomics
}

\begin{abstract}
Ayse Nur Polat ${ }^{\star a b}$ and Nurhan Özlü*a
Protein phosphorylation is a ubiquitous posttranslational modification, which is heavily involved in signal transduction. Misregulation of protein phosphorylation is often associated with a decrease in cell viability and complex diseases such as cancer. The dynamic and low abundant nature of phosphorylated proteins makes studying phosphoproteome a challenging task. In this review, we summarize state of the art proteomic techniques to study and quantify peptide phosphorylation in biological systems and discuss their limitations. Due to its short-lived nature, the phosphorylation event cannot be precisely traced in a heterogonous cell population, which highlights the importance of analyzing phosphorylation events at the single cell level. Mainly, we focus on the methodical and instrumental developments in proteomics and nanotechnology, which will help to build more accurate and robust systems for the feasibility of phosphorylation analysis at the single cell level. We propose that an automated and miniaturized construction of analytical systems holds the key to the future of phosphoproteomics; therefore, we highlight the benchmark studies in this direction. Having advanced and automated microfluidic chip LC systems will allow us to analyze single-cell phosphoproteomics and quantitatively compare it with others. The progress in the microfluidic chip LC systems and feasibility of the single-cell phosphoproteomics will be beneficial for early diagnosis and detection of the treatment response of many crucial diseases.
\end{abstract}

\section{Introduction}

Proteins are composed of small subunits, "amino acids", which are translated from a genetic code. ${ }^{4}$ After translation, the diversity of proteins can be increased by the addition of modifications. ${ }^{5}$ The human genome is resourced with the static information of genes whereas the proteome expands this to multiple different species of proteins by covalent modifications and non-covalent interactions. ${ }^{6,7}$ Traditionally, using the Edman degradation reaction, amino acids are sequenced via labelling the terminal amino acid residue and cleaving it from the peptide without disrupting the remaining peptide bonds. ${ }^{\mathbf{8}}$ Unfortunately, this method is not efficient enough to analyze the dynamic proteome and detect different modifications on the proteins. On the other hand, several hundreds of posttranslational modifications are detected by methods based on mass spectrometry (MS). ${ }^{9,10}$ Amongst these identified modifications, peptide phosphorylation is essential for the catalytic activity of kinases with regard to signal transduction. ${ }^{5} \mathrm{~A}$ considerable amount of knowledge has been accumulated over the years on the phosphorylation state of serine, threonine and tyrosine side chains; additionally, phosphorylation of histidine, arginine, and possibly lysine have also been reported to a far

${ }^{a}$ Department of Molecular Biology and Genetics, Science Faculty, Koç University, Istanbul, Turkey.E-mail: anpolat@ku.edu.tr; nozlu@ku.edu.tr ${ }^{b}$ Schools of Engineering and Science, Jacobs University, Bremen, Germany less extent, and their role in signal transduction is yet to be determined. ${ }^{\mathbf{1 1 - 1 4}}$

Phosphorylation by kinases lies at the heart of signalling pathways; thereby protein kinase and phosphatase activities are attractive research topics. ${ }^{15}$ Misregulation of protein phosphorylation is often associated with decrease in cell viability and diseases such as cancer., ${ }^{1,2}$

Mass spectrometry-based phosphoproteomics technologies have been steadily developed for over a decade; however, studying phosphoproteomics is still quite challenging. Due to low abundance and the physicochemical properties of the phosphopeptides, sample preparation, fractionation and instrumentation techniques are the key steps that determine the success rate of phosphopeptide detection., ${ }^{3,16,17}$ Phosphoproteomics suffers from pitfalls of instrumental techniques and biological systems. Examples include poor reproducibility of MS analysis, time dependence of phosphorylation events, substoichiometric levels of phosphorylated peptides, and cell to cell protein amount and phosphorylation activity variation in a heterogonous population. ${ }^{18}$ In this review, we summarize state of the art proteomic techniques to study protein phosphorylation in biological systems and discuss their limitations and challenges. Due to short life and low abundance, quantifying phosphorylation events in a heterogeneous cell population introduces ambiguity; it would be more accurate to analyze phosphorylation events at the single-cell level. A major barrier to perform phosphoproteomic analysis at the single cell level is the lack of sensitive methods to process very low amounts of the 
material in a single cell for LC/MS. One potential direction towards single cell phosphoproteome analysis is integrating microfluidic systems into proteomics. Having advanced and automated microfluidic chip LC systems combined with effective phosphopeptide enrichment and detection methods would allow us to analyze single cell phosphoproteomics and subsequent quantitative comparison with others. Both the microfluidics and proteomics fields have made tremendous advancements in the last decade and more efforts are being made to take advantage of both technologies. Fig. 1 shows the timeline of landmark studies in proteomics and microfluidics and highlights their intersection in recent years.

One of the first intersections was the use of a lab-on-a-chip system for the separation and fractionation of samples of interest from complex biological systems. ${ }^{19-22}$ Another advanced application is the integration of microfluidics into HPLC-chip systems for MS applications. ${ }^{23-26}$ Detailed reviews have been published by Gao et al. and Feng et al. on the advances in microfluidics and their combination with MS. ${ }^{27,28}$ Therefore, technical advances in microfluidic devices will not be discussed further in this review.

The following sections explain each step of the phosphoproteomics analysis and discuss the progress made towards single-cell phosphoproteomics by making use of microfluidic chip LC systems. We propose that the integration of these two technologies is the next step for phosphoproteome analysis and pushing such integrated technology will open up new avenues of research.

\section{Sample preparation}

Sample preparation is a critical step for increasing the sensitivity of phosphoproteome analysis as reviewed in Ozlu et al. ${ }^{3}$ The type of the sample and the aim of the experiment are the key parameters to decide how to treat samples. In general, cells or tissue samples are lysed with a buffer containing different reagents for various purposes. For example, denaturing agents enhance cell and tissue solubility and protein unfolding. ${ }^{29}$ All sample preparation should be performed on ice to minimize enzyme activities. A mixture of protease inhibitors should be used to prevent undesirable protein degradation. Negatively charged phospho groups are stable on proteins at acidic and physiological $\mathrm{pH}$ conditions; only through a catalytic reaction can phosphatases remove phospho groups. Therefore, a cocktail of phosphatase inhibitors should be used to prevent dephosphorylation. A detailed list of phosphatase inhibitors

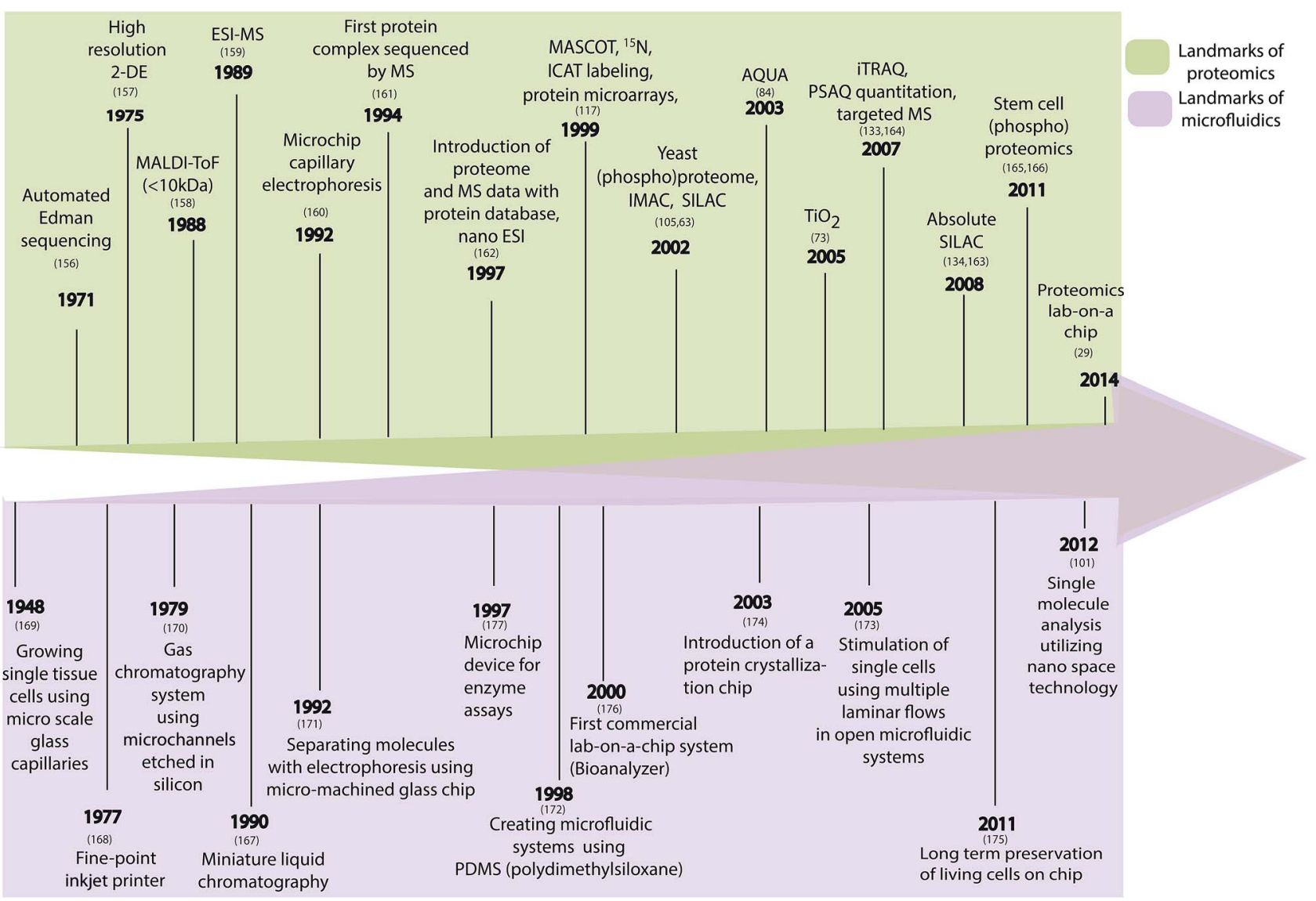

Fig. 1 Milestones for proteomics and microfluidics. This figure indicates milestones for both technologies and their intersection times. Proteomics milestones are based on 'Proteomics of industrial fungi: trends and insights for biotechnology' by de Oliveira et al. $8,28,60,65,75,86,106,118,134,135,159-171$ and microfluidics milestones are based on 'Timing is everything: using fluidics to understand the role of temporal dynamics in cellular systems' by Jovic et al..$^{8,102,171-181}$ 
used in a lysis buffer and their applications can be found in the literature. ${ }^{\mathbf{1 8 , 3 0}}$ Depletion of surfactants and protein inhibitors is a prerequisite for an efficient mass spectrometric analysis; because favourable ionizability of surfactants and relative abundance of some proteins hamper the peptide spectrum. ${ }^{31}$

Different types of proteolytic enzymes can be utilized for protein digestion to generate a specific peptide pool. Unique peptide distributions can be obtained with different sequence characteristics, length, solubility and charge using an appropriate choice of enzymes. Lys-C, trypsin and Lys-N are the most commonly used proteolytic enzymes; each of them cleaves the proteins at specific sites. Trypsin cleaves the C-terminal side of lysine and arginine residues; its activity is strictly dependent on the buffer and the concentration of reagents. ${ }^{32}$ Trypsin with Lys$\mathrm{C}$ is a popular enzyme combination for the CID and HCD fragmentation based MS analysis. ${ }^{33}$ Conversely, LysN, that cleaves at the N-terminal side of lysine, is a commonly used enzyme to generate simplified fragmentation spectra during ETD fragmentation. ${ }^{34-36}$ Using a different combination of proteolytic enzymes would increase the coverage of phosphoproteome. $^{37}$

Fig. 2 shows the general workflow of a typical phosphoproteomic study, which has multiple steps with various tasks. Each step has a possibility of sample loss and contamination introduction. Single cell level studies testify to the power of microfluidics as lab-on-a-chip systems for sample preparation and digestion due to their liquid handling capacities and capability to manipulate single cells in one system. These systems can provide highly accurate measurements even for very low abundant species in a complex mixture because of their sensitivity and compatibility with high-throughput detection and selection systems. ${ }^{38,39}$

Microfluidic systems can be integrated into phosphoproteomics at the very first stage of the workflow while dissecting part of tissue or selecting the required cell population. Agresti et al. have used an integrated drop-based microfluidic device to establish an ultrahigh-throughput screening platform. ${ }^{39}$

Their platform consists of two devices. The first mixes yeast cells with fluorogenic substrates and generates low picoliter volume droplets. The second device redirects these droplets and subsequently sorts the cells according to their dielectrophoretic forces. The sorting of cells is based on the intensity of fluorogenic substrates binding to the enzymes on the cell surface. Since the cells remain encapsulated in the droplets, the entire reaction vessel is assayed and sorted with this microfluidic system. Using a microfluidic design instead of the traditional fluorescence-activated cell sorting (FACS) not only increased the rate of screening to 1000 -fold but also the versatility of cells. ${ }^{39}$

Marcy and colleagues have performed a promising study for the integration of microfluidic systems into a biochemical process. They used a fabricated microfluidic device to lyse the isolated cells and amplify their genetic material. ${ }^{38}$ Another noteworthy phosphorylation study done by Jen et al. reported lysis of HeLa cells using a micro-well device with $20 \mu \mathrm{m}$ diameter for single-cell-based chemical lysis experiments. At the single-cell level, cells are fully lysed 12 seconds after the lysis buffer injection. ${ }^{\mathbf{4 0}}$ These studies propose that microfluidic devices are suitable for multiple single-cell applications from cell lysis to monitoring biochemical activities. Integration of microfluidic devices with different capabilities can enable us to perform single-cell phosphoproteomics analyses on chips. Therefore, phosphoproteomics analysis can greatly benefit from microfluidics based chip systems for high throughput studies. ${ }^{41,42}$

\section{Phosphopeptide analysis by LC-MS}

\section{Phosphopeptide fragmentation}

Phosphopeptide sequencing by tandem MS can induce the loss of labile phosphate groups and makes assigning the phosphosite to the correct residue challenging. Determining the sitespecific phosphorylation is complicated because CID typically results in the partial elimination of the phosphoric group $\left(\mathrm{H}_{3} \mathrm{PO}_{4}, 98 \mathrm{Da}\right.$ or $\mathrm{HPO}_{3}, 80 \mathrm{Da}$, neutral loss $)$ of phosphoserine and phosphothreonine, ${ }^{\mathbf{4 3}}$ whereas phosphotyrosine does not allow the loss of phospho-group because of the aromatic ring. But, occasionally, an irregular loss of $\mathrm{HPO}_{3}$ from phosphotyrosine and $\mathrm{H}_{2} \mathrm{O}$ from another residue is also evident. ${ }^{3,44}$ The low abundance of the phosphopeptides is a well-known issue such that choosing a fragmentation method can be crucial for the phosphoproteome analysis. Since the analysis of phosphorylation at the single-cell level will be more demanding, the sensitivity and the coverage of the detection need to be improved. This can be achieved by combining different fragmentation methods. ${ }^{45-50}$

\section{Sample fractionation}

Dynamic range and the peptide sequencing speed of the instrument are two main limiting factors of the complex peptide mixture analysis and prevent full proteome identification. ${ }^{51}$ Phosphorylated peptides are under-represented in a complex sample and their detection by MS is further impaired by low ionization efficiency and signal suppression. Thus, enrichment and fractionation techniques are obligatory for phosphoproteomics studies. ${ }^{52}$

In proteomics, the majority of the sample analysis is performed by reversed phase chromatography coupled with tandem mass spectrometry (nanoLC-MS/MS). Although recently developed instruments have high resolving power and detection speed, pre-fractionation of samples prior to MS analysis is a prerequisite for a comprehensive analysis. ${ }^{53}$ Their use in phosphoproteomics is limited by their capability to resolve highly complex protein samples like whole cell lysates. Thus, a singlecell analysis would require massive optimization of several parameters, from liquid flow rates, chip channel dimensions to waste lines and mixing chamber distributions. Therefore, wellknown phosphoproteomics protocols should be adapted for microfluidic device dimensions.

Different strategies can be utilized at different stages of the workflow for this purpose. Employing an additional agent at the enrichment stage can increase the selectivity, or reagents can be used for signal enhancement by improving sample solubility and spray. For example, Winter et al. have shown that a citrate 


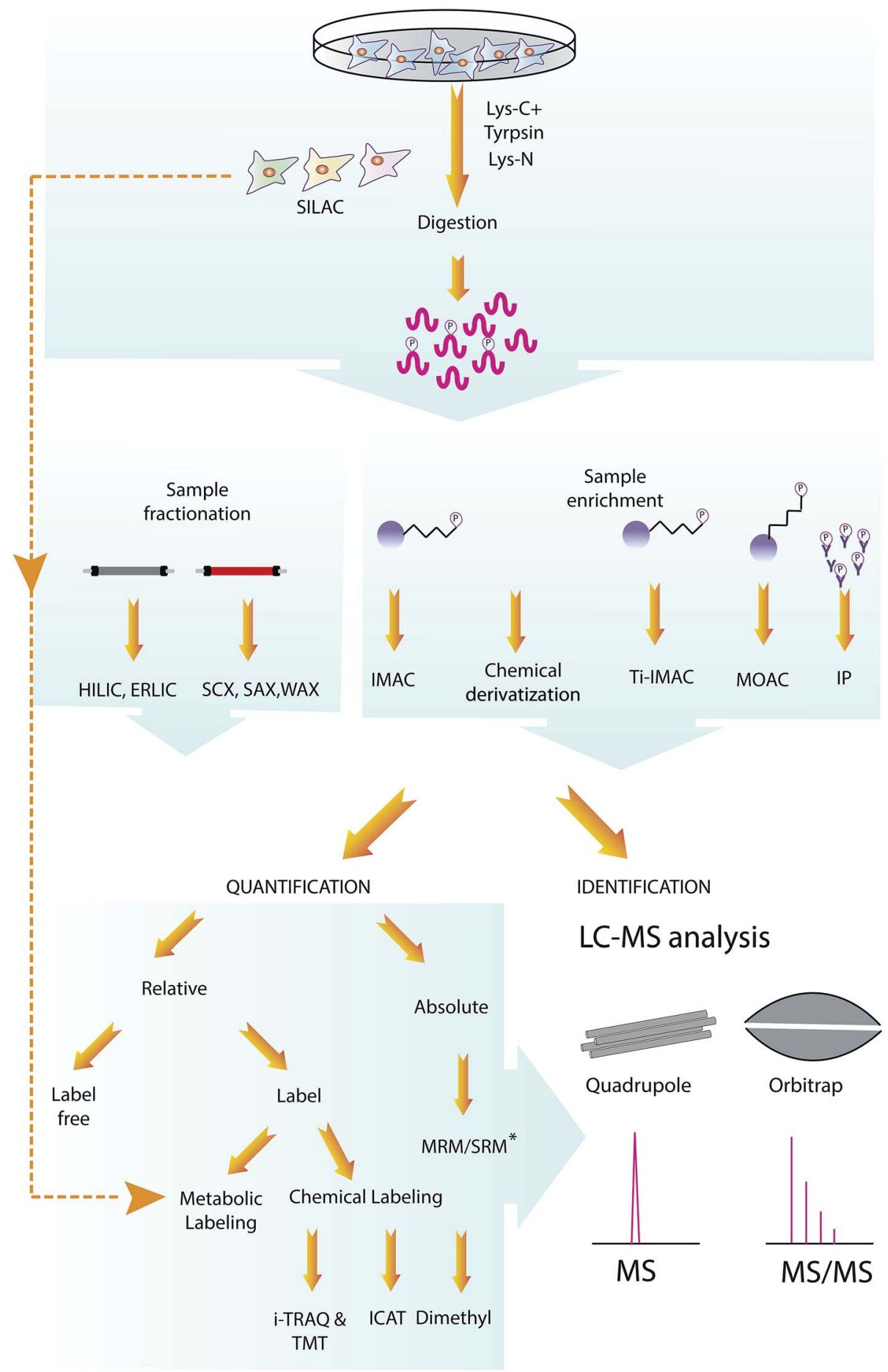

Fig. 2 General phosphoproteomics workflow. This figure illustrates the general proteomic workflow and additional steps such as labeling, enrichment and fractionation. *MRM/SRM are also used for relative quantification.

addition to the phosphopeptide sample could effectively improve the sensitivity of LC-MS analysis of phosphopeptides. ${ }^{54}$

Larsen $e t$ al. also have shown that binding of highly acidic peptides onto the $\mathrm{TiO}_{2}$ material can be circumvented by adding DMSO (dimethyl sulfoxide), KF (potassium fluoride) and $\mathrm{HNa}_{2} \mathrm{PO}_{4}$ (sodium phosphate dibasic) to the loading buffer. A study by Ficarro et al. has demonstrated that using low flow rates at the nanoliter range can enhance the phosphopeptide detection. ${ }^{55} \mathrm{~A}$ recent study from the Kuster group revealed the importance of spray to enhance phosphopeptide detection. They used DMSO to improve the solubility and evaporation efficiency. ${ }^{54,56}$

Several other LC methods based on different chemical properties of peptides have been developed for sample 
fractionation. Therefore, using a combination of different separation procedures is required to increase the peak capacity, and the overall LC resolving power. The most commonly used methods are ion exchange chromatography (SCX), strong anion exchange (SAX), weak anion exchange (WAX) hydrophilic interaction liquid chromatography (HILIC) and electrostatic repulsion-hydrophilic interaction chromatography (ERLIC). ${ }^{51,55,57-59}$

The frequent use of and the new improvements in microfluidics are contributing greatly to single-cell proteomics at different stages of the process like single-cell trapping, lysis, separation, and analysis. It has become possible to use extended nano-space by down-scaling the size of the microfluidic to nanofluidics. ${ }^{19,22}$ The extended nano-space helps to manipulate biological systems efficiently according to their physicochemical properties which lead to enhanced performances by rapid, time efficient and reagent-consuming reactions. This results in reproducible and high throughput data for single-cell phosphoproteomics. ${ }^{60}$ A recent study published by Huft J. and colleagues showed a successful integration of a microfluidic device to a solid phase LC. They automated a multifunctional platform, which permits flexible generation and complex manipulation of low picoliter-scale droplets. Their study supports that this kind of design can handle enzymatic assays and DNA purification at the single-cell level. ${ }^{61}$

Improvements in technology will make microfluidic parts for the LC systems cheaper and more disposable which will increase the quality of the chromatographic separation. Also, working with such a miniaturized system will allow us to exploit the resolution of the chromatography accordingly.

\section{Phosphopeptide enrichment}

Systematic and large scale analysis of the phosphorylation events in a cell is challenging because of the dynamic range and the complexity of the sample. Physicochemical properties of phosphopeptides are predictable so that they can be fractionated and enriched using multiple methodologies. But each additional step introduced into the workflow also introduces a new possible error and variant into the analysis. To maximize the analytical sensitivity, the workflow should be as simple as possible, with relatively few sample preparation steps, so as to prevent the loss of phosphopeptides. To increase the coverage and sensitivity, samples should be handled cautiously prior to analysis. Similarly, a robust system is needed to minimize the variation across the replicates. The introduction of microfluidic chip systems and their automation for sample preparation and fractionation is an effective solution to prevent sample losses and to enhance reproducibility. Employing microfluidic devices minimizes the sample and reagent consumption; it also helps us manipulate the physicochemical properties of the reagent. Consequently, by using microfluidic chips, we can design a controllable, repeatable and rigid system for sample analysis. In the previous section we briefly explained the fractionation methods, and in this section we will continue with enrichment techniques and applications. Although several selective targeted phosphoproteomics methods have been developed and are widely used, lab-to-lab enrichment efficiency and identification rates differ for the same protocol. ${ }^{62}$ Obtaining full coverage of the phosphoproteome using various enrichment strategies with a combination of fractionation techniques is still a demanding task. A wide range of techniques has been developed to enrich the population of phosphopeptides. These enrichment methodologies are based on different principles and are employed according to their orthogonality, with each having its own advantages and disadvantages. ${ }^{63}$ The most frequently used techniques are HPLC-based fractionation, and antibody affinity chromatography (immuno-precipitation (IP)), immobilized metal ion affinity chromatography (IMAC), metal oxide affinity chromatography (MOAC) and chemical derivatization based chromatography. ${ }^{64-67}$ Although MOAC, SIMAC and IMAC have quite similar principles, we will explain each in a separate section to highlight the slight discrepancies among these methods.

IMAC. The IMAC method is based on the affinity of positively charged metal micro-particles $\left(\mathrm{Fe}^{3+}, \mathrm{Al}^{3+}, \mathrm{Co}^{2+}, \mathrm{Ga}^{3+}, \mathrm{Ti}^{4+}\right)$, forming a stationary phase that captures negatively charged phosphopeptides under acidic conditions and releases at alkaline $\mathrm{pH}^{68,69}$ Non-specific binding of acidic peptides is a major obstacle to this technique. ${ }^{70}$ One approach to circumvent this shortage is through $O$-methyl esterification which derivates carboxyl groups on acidic residues into less acidic functional groups. This approach increases the specificity for the selective phosphopeptide detection. ${ }^{71,72}$ IMAC has frequently been coupled with strong cation exchange chromatography (SCX), and hydrophilic interaction liquid chromatography (HILIC). These systems are used prior to the IMAC enrichment to reduce sample complexity and to amplify selectivity towards phosphopeptides. ${ }^{73}$

MOAC. MOAC is an alternative method to IMAC which uses a similar binding chemistry. In this method, acidic residues are neutralized by protonation with the acidification of the loading buffer. As phosphopeptides retain their charge at highly acidic $\mathrm{pH}$, their binding affinity to metal oxide functionalized $\mathrm{ZrO}_{2}$ and $\mathrm{TiO}_{2}$ beads is enhanced. ${ }^{64}$ The phosphate group of a phosphopeptide binds to the oxide groups of the $\mathrm{TiO}_{2}$ beads in bidentate mode. ${ }^{72} \mathrm{~A}$ drawback of this method is the non-specific binding of acidic non-phosphopeptides. Employing an additional agent at the enrichment stage can increase the selectivity and partly overcome this shortage. For example, using a low $\mathrm{pH}$ loading buffer containing reagents such as 2,5-dihydroxybenzoic acid (DHB), dimethyl sulfoxide (DMSO), phthalic acid, and glycolic acid reduces the nonspecific binding of acidic peptides. $^{\mathbf{7 4}}$

Winter et al. have shown that phosphopeptide enrichment sensitivity could be improved by using phosphate, EDTA or citrate as a chelating reagent. ${ }^{54} \mathrm{~A}$ similar study by Larsen et al. also showed that binding of highly acidic peptides onto the $\mathrm{TiO}_{2}$ material can be circumvented by adding DHB to the loading buffer. $^{75}$

To our knowledge, phosphopeptide enrichment by using $\mathrm{TiO}_{2}$ beads is a widely used method because of its offline and online applications and compatibility. ${ }^{76}$ Thus, this method has been successfully coupled with reverse phase liquid 
chromatography. Furthermore, a novel microfluidic chip device based on a $\mathrm{TiO}_{2}$ column integrated to RP-HPLC-MS is manufactured by Agilent. This HPLC-chip enables applications like fully automated phosphopeptide quantification. ${ }^{77-79}$

SIMAC. Several different phosphopeptide enrichment methods have been well-established and their weak and strong features rigorously evaluated. ${ }^{80}$ To increase the identification rate of phosphopeptides, different enrichment methods are combined for sequential elution from the IMAC (SIMAC) method. ${ }^{81}$ This method combines strengths of both IMAC and $\mathrm{TiO}_{2}$ and allows the enrichment of both mono- and multiphosphorylated peptides from complex samples. The rationale behind this methodology is to elute multi-phosphorylated and mono-phosphorylated peptides differently based on their binding efficiency to IMAC beads. Mono-phosphorylated peptides are eluted from the IMAC beads under an acidic condition. As the second step, $\mathrm{TiO}_{2}$ chromatography is applied to these eluates and flow-throughs to remove most of the nonphosphorylated peptides from the pool of mono-phosphorylated peptides in a complex mixture. IMAC has a stronger selectivity for multi-phosphorylated peptides; for these peptides a parallel IMAC chromatography is performed. Phosphopeptides are eluted under a basic condition, which selectively elutes multi-phosphorylated peptides from the IMAC beads. This method has found its own application in large-scale phosphoproteomics experiments. ${ }^{64,76,82,83}$

Immuno-precipitation (IP). Phosphorylation of tyrosine has key functions for most of the signalling pathways. But in a mammalian cell, phosphorylation of tyrosine occurs at low frequency compared to those of serine and threonine..$^{84}$ Thus, the enrichment of phosphotyrosine requires explicit methods like immuno-precipitation (IP). Phosphopeptide enrichment using IP is strictly limited by specificity, lot-to-lot variability of the antibody and reproducibility of the enrichment protocol. ${ }^{85}$ IP can be performed at protein or peptide levels by using phosphotyrosine antibodies. ${ }^{86,87}$ Several IP experiments should be carried out in parallel to acquire a comprehensive set of phosphotyrosine peptides. ${ }^{\mathbf{6 6}, 88}$ Thus, this method is not feasible for experiments with a limited sample amount. Performing IP experiments at the peptide level is more effective. ${ }^{89}$ However, using IP strategies at the peptide level requires a large amount of protein as the starting material. ${ }^{90}$ Recent studies on microarrays and phosphotyrosine antibodies showed that one can enrich different phosphotyrosine populations by using different types of antibodies. ${ }^{91}$ Therefore, antibody cocktails will likely be more popular for this sort of strategy.

Ti-IMAC. Recently, a new phosphopeptide enrichment protocol has been successfully used by the Heck group. ${ }^{92}$ This method is based on $\mathrm{Zr}(\mathrm{Iv})$ or $\mathrm{Ti}(\mathrm{Iv})$ phosphate/phosphonate chemistry, chelation and immobilization of $\mathrm{Ti}^{4+}$ via coordination between $\mathrm{Ti}^{4+}$ and the $\mathrm{P}-\mathrm{O}$ bond of the phosphate group. ${ }^{92,93}$ Structural improvements on Ti-IMAC materials made this method more orthogonal with other peptide fractionation techniques such as SCX and HILIC. ${ }^{73}$

Promising results for the miniaturization of LC systems as microfluidic devices (HPLC chips) for sample enrichment and fractionation have been published. Several nano-LC-chip systems have been commercialized by different vendors, such as $\mathrm{TiO}_{2}$ enrichment, HILIC fractionation, and protein digestion chips. ${ }^{77,79,94-97}$ Ti-IMAC based nano-LC-chip systems will be beneficial for selective and sensitive phosphopeptide enrichments of small materials such as a single cell. The next challenge is to establish the full phosphoproteomics workflow in one automated system (Fig. 3).

Chemical derivatization. Various chemical derivatization protocols are based on a specific reaction under strict conditions. Thus, most of the developed phosphopeptide enrichment protocols have low efficiency and low reproducibility. General application of a particular derivatization protocol for a wide range of applications is almost impossible. Beta elimination of the phosphate group from phosphoserine and phosphothreonine under basic conditions is possible but its efficiency is strictly dependent on the peptide sequence. ${ }^{98,99}$ In addition, this approach cannot be used for the phosphotyrosine peptides. Another similar approach is to replace the phosphate group with biotinylated tags. This approach is also not applicable to phosphotyrosine residues but can modify phosphoserine and phosphothreonine $O$-glycolysated forms and un-modified residues. ${ }^{\mathbf{1 0 0}}$ Because of the non-specific reaction and low reproducibility of the approach, it has yet to be improved for compatibility with other enrichment strategies.

Table 1 presents a review of potential applications of the current phosphoproteomics methods integrated into microfluidics. Each method's compatibility and future adaptations to the microfluidic systems are rated as low, moderate or high with respect to their current trends and applications. Since several successful applications have already been published with IMAC and MOAC based enrichment methods, they are rated as highly compatible. Chemical derivatization is rated as moderate because its application is dependent on the microfluidic designs. A complicated design with well-defined fluid trafficking is required to prevent side reactions caused by residual chemicals. Designing such systems would take a long time and require a lot of expertise in the microfluidic field. IP based enrichment strategies are the least compatible with microfluidics. The implementation of these protocols into a microfluidic chip is demanding, since the reproducibility of the IP enrichment protocols are low, and highly specific antibodies are needed for high affinity binding.

Polat et al. have recently published another example of employing a microfluidic device to perform a phosphoproteomic enrichment method. A chip LC system was used which consists of four columns; a $\mathrm{TiO}_{2}$ column is placed in between two reverse phase (RP) columns and followed by an analytical column. The first RP column was used for quantitative labelling and cleaning followed by a $\mathrm{TiO}_{2}$ column where the phosphopeptide enrichment was conducted. A second RP column was employed for the controlled release of the sample from the analytical column to be processed by MS analysis. This automated system was shown to be sensitive (10-fold ratio differences measured successfully), efficient (high labelling and enrichment efficiency), highly reproducible, less time and sample consuming ( $1 \mu \mathrm{g}$ sample, and the whole analysis time was 8 hours instead of a whole day) and robust. ${ }^{77}$ Thus with this 


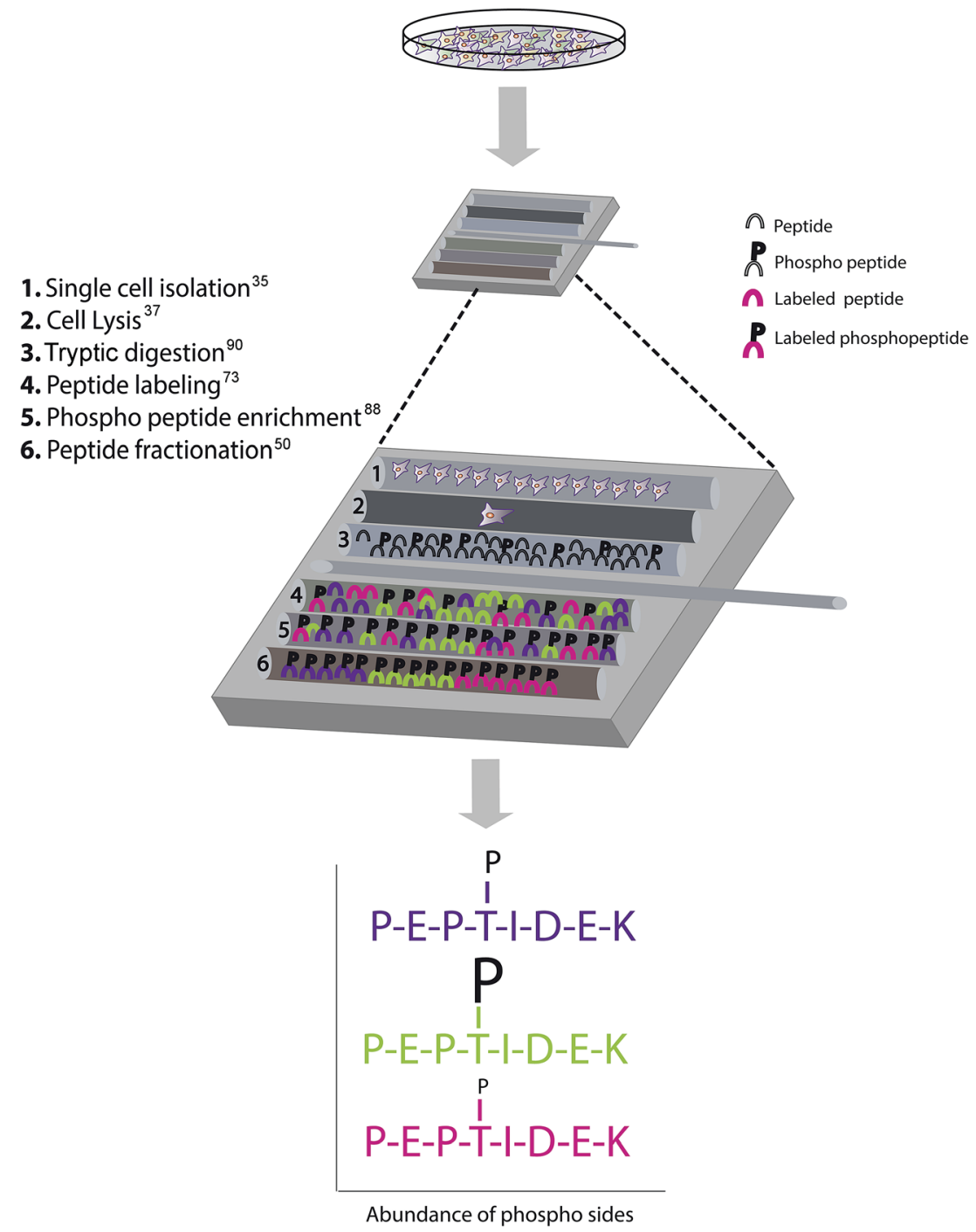

Fig. 3 Hypothetical design of a microfluidic chip for quantitative phosphoproteomics. This hypothetical design combines all essential steps for quantitative phosphoproteomics. Each individual step is performed in the cited studies and its successful implications are discussed in the text. Employing such a microfluidic chip system for a single-cell phosphoproteomics experiment will automate the procedure, which will lead to high throughput results.

approach, comparable results can easily be achieved in high throughput studies. Several studies have been conducted on phosphoproteins by either labelled or label-free quantification strategies. Only a few were performed by using microfluidic/ chip LC and single-cell systems. ${ }^{77,79,96,101}$ Up to now, phosphoproteomics studies mainly used averaged extrapolated results from heterogeneous cell populations; however, as it will be further discussed in the coming sections, individual cell analysis is more definitive and accurate compared to population analysis. ${ }^{102}$

\section{Quantitative proteomics}

Quantification of phosphoproteome is essential for studying its dynamic nature and has greatly benefited from the development of advanced instruments, new software, and sample preparation methods. Different types of labels can be introduced at various stages of the workflow. ${ }^{\mathbf{1 0 3 , 1 0 4}}$ The step where quantification is introduced into the workflow and the quantification strategy should be considered carefully which vary largely based on the question being addressed.

Different strategies such as chemical labelling, metabolic labelling, label-free and absolute quantification strategies have been employed in several studies. ${ }^{105}$ In this section we will briefly explain the principles of the methods and their successful adaptations for quantitative studies. Common quantification strategies can be broken down into two main categories: relative quantification and absolute quantification. The idea behind microfluidics is to minimize user interference and maximize the automation to prevent bias and contaminations prior to quantification. In general, microfluidics will be most beneficial for quantitative analysis since it provides accurate and consistent sample-to-sample reproducibility. 
Table 1 A review of potential applications of the current phosphoproteomics methods to microfluidics. Each enrichment method's pros and cons and with future adaptations its compatibility to the microfluidic systems are rated as low, moderate or high

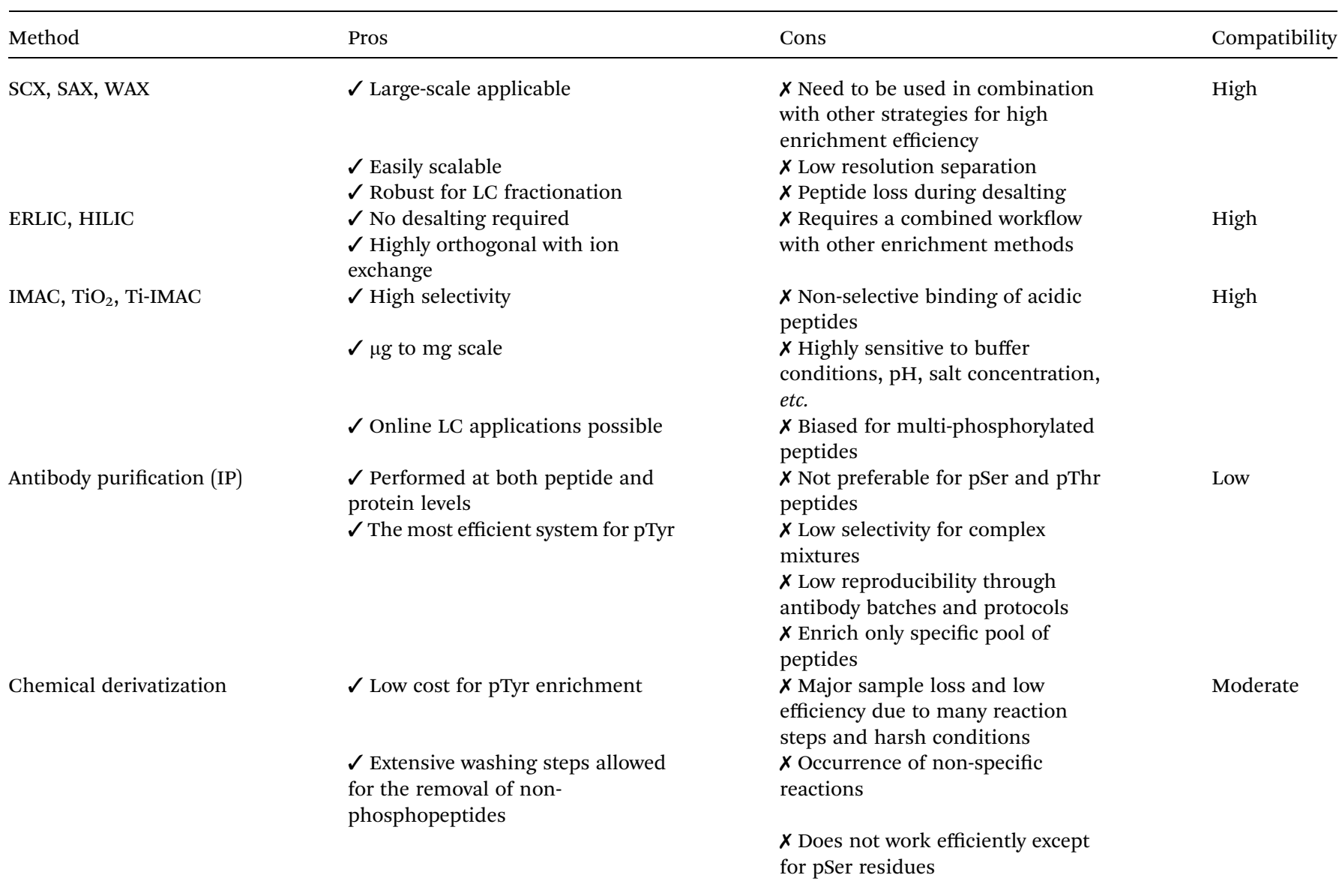

Metabolic labelling. Metabolic labelling is introduced during the cell growth and division by the substitution of the natural ${ }^{14} \mathrm{~N}$ or ${ }^{12} \mathrm{C}$ sources with their heavier isotopes, such as ${ }^{15} \mathrm{~N}$ or ${ }^{13} \mathrm{C}$, or by substituting one or more essential amino acids with their heavy-labelled counterparts to obtain complete incorporation of the synthesized proteins. ${ }^{\mathbf{1 0 6}}$ The main advantage of metabolic labelling is the incorporation of a label in a living cell at the earliest stage of the work flow. Samples can be combined before the sample preparation steps and any error arising from the sample handling steps will be identical for each sample. The quantification accuracy will be equally affected for each sample. Metabolic labelling is commonly used in invertebrate model organisms such as yeast, Caenorhabditis elegans and Drosophila melanogaster; a new metabolic labelling method introduced by the Yates lab extended this technique to an entire mammal. The SILAM (stable isotope labelling of mammals) labelling of rodents was performed with a diet of ${ }^{15} \mathrm{~N}$-enriched (>99\%) blue-green alga Arthrospira platensis, as the sole protein and nitrogen source for the animal. ${ }^{\mathbf{1 0 7}}$ Rauniyar et al. have demonstrated the quantitative application of SILAM to analyze protein expression levels in the rat brain at two different developmental stages. They found that ${ }^{15} \mathrm{~N}$ labelled rat can be an optimal source of a tissue-specific internal standard to facilitate quantitative proteomics. ${ }^{\mathbf{1 0 8}}$ As the incorporation reaction is quite specific apart from the preventable arginine to proline conversion, no side reactions or side products have been observed in the sample. ${ }^{109}$ The limiting factors for the use of this method are the time required and the cost of the experiment.

SILAC. The most frequently used metabolic labelling method is the stable isotope labelling by amino acids in cell culture (SILAC). ${ }^{106}$ Simply, this procedure involves in vivo incorporation of the stable isotope containing versions of essential amino acids (especially arginine, lysine and leucine) during the cell growth and division. Arginine and lysine residues are particularly popular since trypsin cleaves peptides at the carboxyl terminal of these amines; when SILAC is combined with trypsin digestion, every peptide will be labelled at the carboxylterminus. After several cell doublings, the complete cellular proteome is labelled with the isotope-containing amino acids. ${ }^{110}$ The number of labelling channels for this method is limited to three but this can be extended to four or five labels at the expense of accurate quantification. A recent paper published by the Augustin group established 5-plex SILAC, which was employed to monitor phosphotyrosine signalling perturbations induced by drug treatment. SILAC is generally used for 
cell systems that are grown in a culture but has limited use for body fluids and tissues. ${ }^{\mathbf{1 0 6}, \mathbf{1 1 0 - 1 1 2}}$ New SILAC applications are also emerging, like SILAC labelled mice. ${ }^{113}$ By in vivo labelling, the entire proteome prior to sample preparation prevents quantitative labelling based sample loss; therefore, we believe that in the future the SILAC method will be the method of choice for single-cell relative quantification studies.

Chemical labelling. When metabolic labelling cannot be used due to sample related reasons, chemical labelling can be an alternative solution for the quantification. For chemical labelling, any reactive group of peptides can be targeted and altered by labels, particularly the peptide/protein N-terminus and $\varepsilon$-amino group of lysine. ${ }^{\mathbf{1 1 4}}$ One of the primary disadvantages of the chemical labelling method is side reactions and side products, which may complicate the MS detection and spectra analysis. Peptide precursor ions (MS) and/or fragment ions (MS/MS) can be utilized for the quantification. Another accepted method for chemical labelling is stable-isotope dimethyl labelling. ${ }^{\mathbf{1 1 5 , 1 1 6}}$ This method targets the primary amine groups (lysine and amino termini) of proteins/peptides. Three channels of labels can easily be generated by using a combination of isotopomers of formaldehyde and cyanoborohydride, including isotopes ${ }^{2} \mathrm{H}$ and ${ }^{13} \mathrm{C} .{ }^{103,105}$ Since deuterium has different physical and chemical property compared with the hydrogen analogue, the deuterium effect reveals itself as retention time shifts during liquid chromatography (LC) separations. Although ICAT itself is not an isobaric tagging strategy, developing this method was the first step for isobaric taggingbased quantification. The implementation of two isobaric tagging quantification methods, isobaric tags for relative and absolute quantification (iTRAQ) and tandem mass tag (TMT) have increased the popularity and usage of chemical labelling for proteomics. ${ }^{115-118}$

Stable-isotope dimethyl labelling. Dimethyl labelling is applied to a sample at the peptide level generally after tryptic digestion; each label differs from others by at least $4 \mathrm{Da} \cdot{ }^{119,120}$ The low cost of this method and micrograms to milligrams of sample labelling range, its well established labelling protocols and applicability to any biological experiment make it a newly emerging quantitative method for many research studies. ${ }^{121}$ A drawback of this method is the deuterium effect during LC separations, which can affect the quantification. ${ }^{\mathbf{1 2 2 , 1 2 3}}$ But this effect can be minimized by using the retention time alignment software. Dimethyl labelling can prevent nonspecific binding of phosphopeptides to IMAC columns, with esterification of the acidic groups such as C-termini of peptides and carboxylic acids in the side chains of glutamic and aspartic acids. Consequently, this method can improve the enrichment of the phosphopeptides. ${ }^{77,79,85}$

ICAT. ICAT (isotope-coded affinity tags) labelling is performed at the protein level. This chemical labelling strategy works based on its specificity towards sulfhydryl groups and consists of an isotopically coded linker and an (biotin) affinity tag for the purification of labelled proteins/peptides. Its applicability is only for cysteine-containing proteins which reduces the reliability of quantification and limits the number of labelling channels; as a result, ICAT is less popular compared to other methods. ${ }^{115,118,124}$
Isobaric labelling (iTRAQ and TMT). The isobaric tag for relative and absolute quantification (iTRAQ) and the tandem mass tag (TMT) have the main advantage of multiplexed analysis of four, six, eight, or 10 samples within one experimental setup. These isobaric labels consist of three different components: reporter, balance and reactive regions. $N$-Hydroxy-succinimide ester is employed for the reaction with primary amines of the peptide N-termini chemistry. Through MS, isobaric labelled peptides cannot be distinguished so that MS spectra will be less complicated, but relative abundance can be determined when the MS/MS reporter ion cleaves off during fragmentation. This multiplexing strategy is presented in 4- or 8plex formats for iTRAQ, and 6 or 10-plex formats for TMT. A good chromatographic separation to diminish co-elution of peptides and a ToF or HCD capable instrument allowing quantitation of low $\mathrm{m} / \mathrm{z}$ fragmentation ions are required for better quantification by using an isobaric tag.

Recently, a detailed study comparing both identification and quantification of iTRAQ/TMT, SILAC, dimethyl labelling was published by the Heck group. ${ }^{\mathbf{1 2 5}}$ Triple labelled samples were used for SILAC, dimethyl and iTRAQ/TMT, and a separate 6-plex iTRAQ/TMT was employed to judge the performance of a complex design. Their results showed that SILAC and dimethyl labelling are both similar for quantification and identification. On the other hand, iTRAQ/TMT had a lower rate for MS2 based quantification due to the co-isolation problem. Their most precise quantitative results were obtained from MS2/MS3 based TMT experiments. Finally, the Heck group suggested using SILAC for affinity purification MS experiments and dimethyl labelling for primary cell cultures of tissue samples. ${ }^{123}$

Label-free quantification. In the absence of labels one can use a label-free approach for the peptide/protein quantification. This method uses either a precursor intensity calculation, a spectral counting method (total number of the identified peptide-to-spectrum matches, PSMs, per protein) or a sequence coverage for each protein. ${ }^{\mathbf{1 2 6 , 1 2 7}}$ An indefinite number of samples can be compared with label-free methods but a label-free quantification experiment requires multiple analyses of each sample and separate analysis for each condition. As a consequence, label-free experiments can be elaborate and time consuming.

Both intensity calculation and spectral counting based labelfree approaches need a robust LC system and high precision MS for high reproducibility and to align the retention time and $\mathrm{m} / \mathrm{z}$ of peptides in between analyses. Label free quantification using precursor intensity is based on extracted ion chromatogram (XIC) of the peptide of interest. Peptide/protein abundance can be predicted by accumulating differentiations of measured XIC variations. ${ }^{96}$ An internal standard with a known concentration is needed for the relative quantification and normalization. ${ }^{\mathbf{1 2 8}}$ To our knowledge, the most frequently used approach is the spectral counting method because of its sensitivity (dynamic range) and high reproducibility. This method is generally used for the comparison of large datasets. ${ }^{129}$ Results of a relative quantification with spectral counting are strictly dependent on the parameters used and data manipulation. ${ }^{\mathbf{1 3 0}}$ Each step of the 
workflow should be considered carefully for the following: the number of data points, the length and abundance of the peptide, sample concentration, analogy of the sample analysis process, protein identification process, filtering parameters and normalization of data.

A study by Megger et al. investigated three different hepatocellular carcinoma (HCC) cell lines HepG2, Hep3B, and SKHep-1, using both label-free and TMT labelling. In this study, the protein coverage obtained with label-free quantification outperformed the TMT labelling. But the protein identification rates were similar for both approaches. Although reproducibility was comparable for both TMT and label-free methods, TMT had higher quantification accuracy. They also demonstrated the necessity of using HCD fragmentation in combination with TMT labelling. ${ }^{131}$

The message from peptide quantification method comparison studies is universal; they all demonstrate that a quantification strategy should be chosen based on the sample type and design of the experimental workflow.

Absolute quantification (SRM/MRM). SRM/MRM quantification is preferred by many groups because of its highly reproducible, sensitive and accurate nature for both relative and absolute quantification. Absolute protein quantification is performed by adding a known concentration of an internal standard (a peptide containing heavy amino acids or stable-isotopecontaining tags) to the protein digest. Mass spectrometric signals of the standard and endogenous peptide of the sample are compared for the quantification. ${ }^{\mathbf{1 3 2}}$ Different reference peptides/proteins and approaches such as AQUA and QconCAT, protein standard absolute quantification (PSAQ), FlexiQuant (PSAQ), and absolute SILAC are used for the targeted SRM/MRM method. ${ }^{86,133-136} \mathrm{SRM} / \mathrm{MRM}$ is simply the isolation of specific fragments of a peptide and detection of its transitions by using a mass spectrometer.

The transient and dynamic nature of phosphorylation, low abundance of phosphoproteins and lack of phospho-specific antibodies make the targeted absolute quantitative methods desirable. Even though this approach is applicable and favourable for the phosphoproteomics and in general proteomic experimental designs, the determination of one or a few specific phosphoproteins could be quite challenging and time consuming. ${ }^{137}$ Some of the limitations of the SRM/MRM method include: the necessity of discovery experiments for the selection of appropriate internal standards, optimization assays for each peptide of interest, the high cost of internal standard synthesis and bias due to late introduction of internal standards into the sample. ${ }^{\mathbf{1 3 8}}$

Although SRM/MRM requires prior knowledge of peptides/ proteins, it is the most preferred method for the biomarker studies. Due to its sensitive absolute quantification, it is feasible for high-throughput clinical studies. New automation and chip applications will likely strengthen the power of SRM for discovering new biomarkers and extend its application to single-cell studies. ${ }^{\mathbf{1 3 9}}$ In Fig. 3 we show a hypothetical design of a microfluidic chip for quantitative phosphoproteomics. This kind of design can circumvent the introduction of impurities and losses during sample handling. Therefore, it is beneficial to use a combination of this design together with sensitive analysis methods such as SRM/MRM or label-free quantification. All these approaches require minimal variation before and during sample analysis so that the robustness of microfluidic chip systems can significantly improve peptide quantification.

Table 2 presents a review of all quantitation methods discussed above and their adaptations to microfluidic systems for a single cell. Each method is rated based on its potential of integration to the microfluidic systems and its prospects in single-cell phosphoproteome quantification. High reproducibility and robustness are the main strengths of the microfluidics. For label-free and absolute quantification methods no chemical labelling step is involved; only stable LC-MS systems and reproducible analysis with stringent protocols are required. Therefore, they are more compatible with microfluidics. Although numerous applications of chemical labelling using microfluidic HPLC chips have been published, ${ }^{77,140}$ in general their compatibility is debatable. ${ }^{77,78}$ For instance, for TMT and iTRAQ, several different labelling reagents are needed and optimization is a pre-requisite. A comprehensive microfluidic design would be necessary for such labelling strategies, and, as explained in Chemical labelling section, building such systems can be quite challenging. Therefore, chemical labelling is rated as moderate with respect to compatibility. The metabolic labelling strategies on the other hand can be applicable. The previous sections showed examples of on-chip cell growth. Implementing metabolic labelling into such designs could be less demanding compared to the other chemical labellingbased methods. Hence, metabolic labelling is rated as compatible for microfluidics.

\section{Towards single-cell phosphoproteomics}

The dynamic nature of protein phosphorylation and cross-talk between the phosphorylation sites play an essential role in the specificity of signal transduction pathways and in fine-tuning the cellular response. Upon stimulation, protein phosphorylation may rapidly occur and reach its maximum level followed by a decrease in a short period of time. ${ }^{141}$ However, it is not feasible to trace such a dynamic phosphorylation event at a mixed cell population level due to the heterogeneity of cells. Fig. 4 shows a hypothetical example that illustrates the importance of singlecell phosphoproteome in analyzing phosphorylation dynamics and shows plausible discrepancies in quantifying phosphorylation sites in a single cell versus a heterogeneous cell population. In the last decade, studies at the single cell level have revealed new mechanisms in cellular signalling pathways. For example, the oscillatory response of p53 and Nf- $\kappa \mathrm{B}$ signalling systems were only identified by quantitative analysis at the single cell level. ${ }^{142}$ We suspect that many phosphorylation events in eukaryotic cells may have similar dynamics and would only be revealed by phosphoproteomics analysis at the single cell level. The single-cell phospho-analysis approach becomes even more valuable in some fields such as stem cells, developmental biology, and cancer where a small subpopulation of cells 
Table 2 A review of potential applications of the current phosphoproteomics methods to microfluidics. Each quantification method's pros and cons and its compatibility to the microfluidic systems are rated as low, moderate or high with respect to current trends and applications

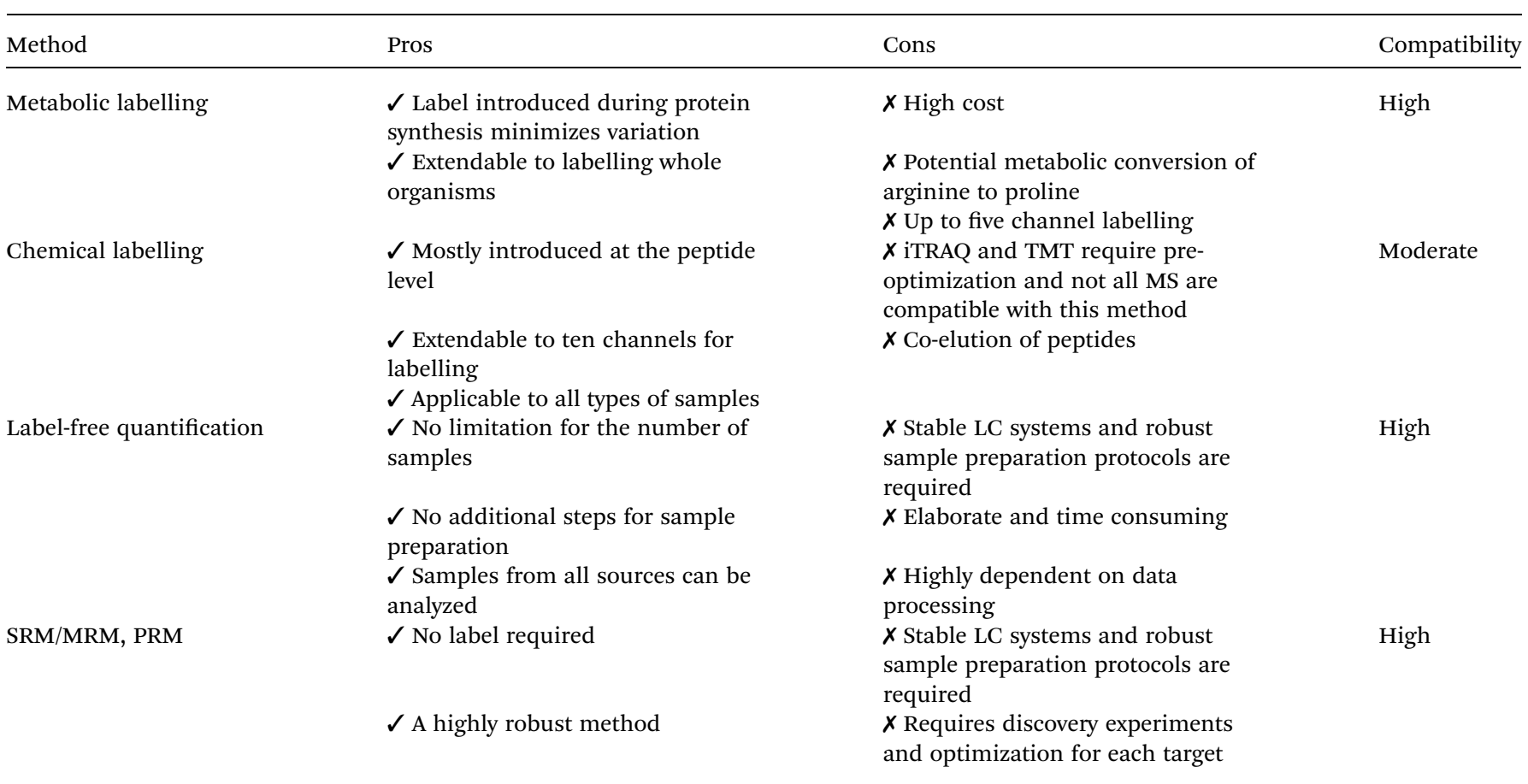

could have the biggest impact on the decision-making of neighbouring cells. For example, reverse transcription quantitative PCR analysis in single cells allowed Diehn et al. to differentiate a subpopulation of cancer stem cells that are tumour radioresistant with lower reactive oxygen species (ROS) and increased expression of free radical scavenging systems. ${ }^{\mathbf{1 4 3}}$

Ma et al. have developed a microfluidic design for the quantitative measurement of complex secreted proteins to assess multiple inflammatory cytokines from human macrophages. ${ }^{41}$ In this study, they employed a single-cell barcode system to assess the content of heterogeneity functionality in a single cell using a clinical microchip. Each channel of the chip was loaded with either single or a small number of cells. Experiments conducted with the microfluidic system showed heterogeneous functional diversity between two pools (healthy vs. patient). They claimed that this system is a high throughput, low cost and portable system, which can be adapted for various fundamental and clinical applications. One can further speculate a derivative of such systems in which phosphorylation events between different pools can be quantified from single cells.

In parallel, developments in nanotechnology will serve the outcome of single-cell analysis since they can enable scientists to manipulate and target at the molecular level in a single cell using nano systems, such as nano-pocket delivery systems with colloidal chemistry, liposome, micelle encapsulation, dendrimers, and carbon nanotubes. ${ }^{\mathbf{1 4 4}}$ More importantly, recent improvements in instrumental technology and material engineering have made sample analysis possible at the attomole level with nanoliter amounts. ${ }^{25}$ The advantage of these systems is specific targeting and safe delivery of agents. In this way, drug releases can be controlled and patient safety will be increased by reducing side reactions and increasing compliance. ${ }^{145,146}$

\section{Limitations and challenges}

Although microfluidic applications are rapidly increasing, there are a few issues that need extra consideration in the mechanics and the fundamentals of devices. Most of the possible issues are the result of the wrong channel design (channel width, depth, junction points) and valves, which eventually affect flow rates, flow streams, shear stress and evaporation. ${ }^{\mathbf{1 4 7 , 1 4 8}}$ Optimization of the system for the corresponding sample is challenging, requiring many parameters to be checked and adjusted..$^{\mathbf{2 0 1 4 9}}$ Most of the mechanical parts are affiliated with another; the switching speed of the valves affects the efficiency of chemical mixing and flow continuation. ${ }^{150}$ Another important aspect is the preservation of viable cells on the chip which is primarily based on the microfluidic chip material and coatings. ${ }^{151}$ Elimination of waste chemicals or side products is also crucial for cell viability and behaviour; therefore, a cell should be isolated enough not to be affected by another's toxic effect. ${ }^{150}$ All these problems have been observed in several studies and various solutions have been found. ${ }^{21}$ This research indicates that the microfluidic designs can also be challenging for inexperienced communities. Thus, stepwise integration of the Lab-on-a-Chip system into the complex quantitative phosphoproteomics workflow is utterly convenient for the transition process. For phosphoproteomics, one of the first applications of nano/micro fluidic-chip LC devices was for the separation and sample preparation steps. ${ }^{152,153}$ 

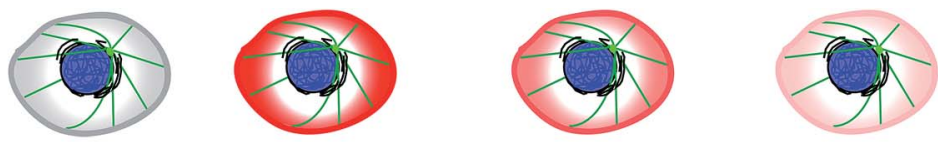

\author{
Stimuli
}

$t=0$

$t=1$

$\mathrm{t}=2$

$t=3$

Single

Cell
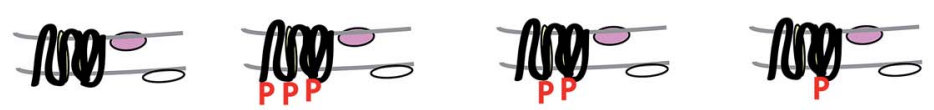

Mixed Cell Population
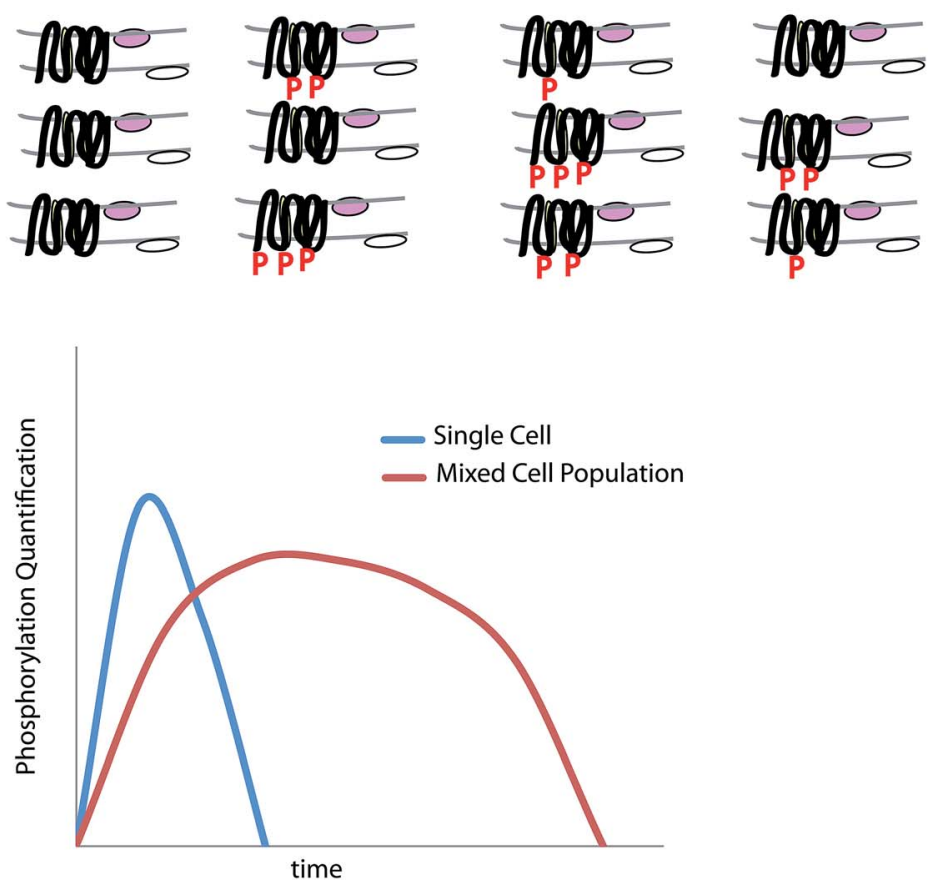

Fig. 4 Schematic illustration of a hypothetical cell surface protein's phosphorylation dynamics upon stimulation in a single cell versus a mixed cell population. An exemplary graph is shown at the bottom. In a mixed cell population, quantifying the abundance of phosphorylation sites would be inaccurate due to the unsynchronized response of different cells upon stimulation.

Different column systems can be easily integrated into micro-devices; thus various methods have been applied on one chip. Mass production limits the system-to-system variation and full integration allows automation of the whole process. Therefore, samples can be separated and analyzed simultaneously and repetitively without any loss. ${ }^{26,154}$ These systems are designed at micro-sizes and require a micro-gram per liter sample. In fact, it is possible to perform femtomole level quantification when microfluidic systems are combined with a sensitive detection system. ${ }^{79}$

Integrated microfluidics has been used for almost twenty years but their adaptation to life sciences has increased dramatically in the last decade due to large-scale applications and mass production. ${ }^{155,156}$ Furthermore, microfluidics provide huge advantages for single-cell analysis, such as scalability, enhancing the concentrations of small volumes, and the ability of handling and lysing single cells. ${ }^{157}$ We could debate that the next step for this technology will be determining phosphorylation regulation at the single cell level, and a limited number of studies support our argument. ${ }^{158}$ However, yet we are far away from global phosphoproteomic analysis in single cells. Improvements in the precision of single cell handling, sample preparation, instrumentation and enhanced sensitivity of phosphopeptide detection will greatly serve to this mission. From the future perspective, this technology will likely be applicable for the diagnosis and treatment of diseases with further advancements in the field of personalized medicine and medical care.

\section{Acknowledgements}

N. Ozlu is financially supported by TUBITAK (The Scientific and Technological Research Council of Turkey) 1001, an EMBO 
(European Molecular Biology Organization) Installation Grant, and a European Union Marie Curie Career Integration Grant. A. N. Polat would like to thank Prof. Dr Nikolai Kuhnert for his supervision and technical input. The authors would like to thank Dr Victoria Taylor for her assistance in the preparation of the manuscript.

\section{References}

1 J. Reimand, O. Wagih and G. D. Bader, Sci. Rep., 2013, 3, 2651.

2 J. Zhang, P. L. Yang and N. S. Gray, Nat. Rev. Cancer, 2009, 9, 28-39.

3 N. Ozlu, B. Akten, W. Timm, N. Haseley, H. Steen and J. A. Steen, Wiley Interdiscip. Rev.: Syst. Biol. Med., 2010, 2, 255-276.

4 A. A. Turanov, A. V. Lobanov, D. E. Fomenko, H. G. Morrison, M. L. Sogin, L. A. Klobutcher, D. L. Hatfield and V. N. Gladyshev, Science, 2009, 323, 259-261.

5 M. Mann and O. N. Jensen, Nat. Biotechnol., 2003, 21, 255261.

6 J. D. Watson, Genome Res., 2001, 11, 1803-1804.

7 J. C. Venter, M. D. Adams, E. W. Myers, P. W. Li, R. J. Mural, G. G. Sutton, H. O. Smith, M. Yandell, C. A. Evans, R. A. Holt, J. D. Gocayne, P. Amanatides, R. M. Ballew, D. H. Huson, J. R. Wortman, Q. Zhang, C. D. Kodira, X. H. Zheng, L. Chen, M. Skupski, G. Subramanian, P. D. Thomas, J. Zhang, G. L. Gabor Miklos, C. Nelson, S. Broder, A. G. Clark, J. Nadeau, V. A. McKusick, N. Zinder, A. J. Levine, R. J. Roberts, M. Simon, C. Slayman, M. Hunkapiller, R. Bolanos, A. Delcher, I. Dew, D. Fasulo, M. Flanigan, L. Florea, A. Halpern, S. Hannenhalli, S. Kravitz, S. Levy, C. Mobarry, K. Reinert, K. Remington, J. Abu-Threideh, E. Beasley, K. Biddick, V. Bonazzi, R. Brandon, M. Cargill, I. Chandramouliswaran, R. Charlab, K. Chaturvedi, Z. Deng, V. Di Francesco, P. Dunn, K. Eilbeck, C. Evangelista, A. E. Gabrielian, W. Gan, W. Ge, F. Gong, Z. Gu, P. Guan, T. J. Heiman, M. E. Higgins, R. R. Ji, Z. Ke, K. A. Ketchum, Z. Lai, Y. Lei, Z. Li, J. Li, Y. Liang, X. Lin, F. Lu, G. V. Merkulov, N. Milshina, H. M. Moore, A. K. Naik, V. A. Narayan, B. Neelam, D. Nusskern, D. B. Rusch, S. Salzberg, W. Shao, B. Shue, J. Sun, Z. Wang, A. Wang, X. Wang, J. Wang, M. Wei, R. Wides, C. Xiao, C. Yan, A. Yao, J. Ye, M. Zhan, W. Zhang, H. Zhang, Q. Zhao, L. Zheng, F. Zhong, W. Zhong, S. Zhu, S. Zhao, D. Gilbert, S. Baumhueter, G. Spier, C. Carter, A. Cravchik, T. Woodage, F. Ali, H. An, A. Awe, D. Baldwin, H. Baden, M. Barnstead, I. Barrow, K. Beeson, D. Busam, A. Carver, A. Center, M. L. Cheng, L. Curry, S. Danaher, L. Davenport, R. Desilets, S. Dietz, K. Dodson, L. Doup, S. Ferriera, N. Garg, A. Gluecksmann, B. Hart, J. Haynes, C. Haynes, C. Heiner, S. Hladun, D. Hostin, J. Houck, T. Howland, C. Ibegwam, J. Johnson, F. Kalush, L. Kline, S. Koduru, A. Love, F. Mann, D. May, S. McCawley, T. McIntosh, I. McMullen, M. Moy, L. Moy,
B. Murphy, K. Nelson, C. Pfannkoch, E. Pratts, V. Puri, H. Qureshi, M. Reardon, R. Rodriguez, Y. H. Rogers, D. Romblad, B. Ruhfel, R. Scott, C. Sitter, M. Smallwood, E. Stewart, R. Strong, E. Suh, R. Thomas, N. N. Tint, S. Tse, C. Vech, G. Wang, J. Wetter, S. Williams, M. Williams, S. Windsor, E. Winn-Deen, K. Wolfe, J. Zaveri, K. Zaveri, J. F. Abril, R. Guigo, M. J. Campbell, K. V. Sjolander, B. Karlak, A. Kejariwal, H. Mi, B. Lazareva, T. Hatton, A. Narechania, K. Diemer, A. Muruganujan, N. Guo, S. Sato, V. Bafna, S. Istrail, R. Lippert, R. Schwartz, B. Walenz, S. Yooseph, D. Allen, A. Basu, J. Baxendale, L. Blick, M. Caminha, J. Carnes-Stine, P. Caulk, Y. H. Chiang, M. Coyne, C. Dahlke, A. Mays, M. Dombroski, M. Donnelly, D. Ely, S. Esparham, C. Fosler, H. Gire, S. Glanowski, K. Glasser, A. Glodek, M. Gorokhov, K. Graham, B. Gropman, M. Harris, J. Heil, S. Henderson, J. Hoover, D. Jennings, C. Jordan, J. Jordan, J. Kasha, L. Kagan, C. Kraft, A. Levitsky, M. Lewis, X. Liu, J. Lopez, D. Ma, W. Majoros, J. McDaniel, S. Murphy, M. Newman, T. Nguyen, N. Nguyen, M. Nodell, S. Pan, J. Peck, M. Peterson, W. Rowe, R. Sanders, J. Scott, M. Simpson, T. Smith, A. Sprague, T. Stockwell, R. Turner, E. Venter, M. Wang, M. Wen, D. Wu, M. Wu, A. Xia, A. Zandieh and X. Zhu, Science, 2001, 291, 1304-1351.

8 P. Edman, Arch. Biochem., 1949, 22, 475-476.

9 G. A. Khoury, R. C. Baliban and C. A. Floudas, Sci. Rep., 2011, 1, DOI: 10.1038/srep00090.

10 R. Aebersold and M. Mann, Nature, 2003, 422, 198-207.

11 H. R. Matthews, Pharmacol. Ther., 1995, 67, 323-350.

12 P. V. Attwood, M. J. Piggott, X. L. Zu and P. G. Besant, Amino Acids, 2007, 32, 145-156.

13 X. L. Zu, P. G. Besant, A. Imhof and P. V. Attwood, Amino Acids, 2007, 32, 347-357.

14 J. Fuhrmann, B. Mierzwa, D. B. Trentini, S. Spiess, A. Lehner, E. Charpentier and T. Clausen, Cell Rep., 2013, 3, 1832-1839.

15 J. D. Graves and E. G. Krebs, Pharmacol. Ther., 1999, 82, 111-121.

16 J. R. Yates, C. I. Ruse and A. Nakorchevsky, Annu. Rev. Biomed. Eng., 2009, 11, 49-79.

17 B. Domon and R. Aebersold, Nat. Biotechnol., 2010, 28, 710721.

18 T. E. Thingholm, O. N. Jensen and M. R. Larsen, Proteomics, 2009, 9, 1451-1468.

19 H. Andersson and A. van den Berg, Curr. Opin. Biotechnol., 2004, 15, 44-49.

20 G. M. Walker, H. C. Zeringue and D. J. Beebe, Lab Chip, 2004, 4, 91-97.

21 P. J. Hung, P. J. Lee, P. Sabounchi, N. Aghdam, R. Lin and L. P. Lee, Lab Chip, 2005, 5, 44-48.

22 M. L. Kovarik and S. C. Jacobson, Anal. Chem., 2009, 81, 7133-7140.

23 D. Reichmuth, T. Shepodd and B. Kirby, Anal. Chem., 2005, 77, 2997-3000.

24 N. Yin, K. Killeen, R. Brennen, D. Sobek, M. Werlich and T. van de Goor, Anal. Chem., 2005, 77, 527-533. 
25 J. Hardouin, R. Joubert-Caron and M. Caron, J. Sep. Sci., 2007, 30, 1482-1487.

26 H. Yin and K. Killeen, J. Sep. Sci., 2007, 30, 1427-1434.

27 D. Gao, H. Liu, Y. Jiang and J.-M. Lin, Lab Chip, 2013, 13, 3309-3322.

28 X. Feng, B.-F. Liu, J. Li and X. Liu, Mass Spectrom. Rev., 2014, DOI: 10.1002/mas.21417.

29 M. Waas, S. Bhattacharya, S. Chuppa, X. Wu, D. R. Jensen, U. Omasits, B. Wollscheid, B. F. Volkman, K. R. Noon and R. L. Gundry, Anal. Chem., 2014, 86, 1551-1559.

30 N. Ozlu, M. Kirchner and J. J. Steen, Methods Mol. Biol., 2012, 795, 217-231.

31 J. R. Wisniewski, A. Zougman, N. Nagaraj and M. Mann, Nat. Methods, 2009, 6, 359-362.

32 J. V. Olsen, J. C. Schwartz, J. Griep-Raming, M. L. Nielsen, E. Damoc, E. Denisov, O. Lange, P. Remes, D. Taylor, M. Splendore, E. R. Wouters, M. Senko, A. Makarov, M. Mann and S. Horning, Mol. Cell. Proteomics, 2009, 8, 2759-2769.

33 P. J. Boersema, S. Mohammed and A. J. Heck, J. Mass Spectrom., 2009, 44, 861-878.

34 N. Taouatas, A. F. Altelaar, M. M. Drugan, A. O. Helbig, S. Mohammed and A. J. Heck, Mol. Cell. Proteomics, 2009, 8, 190-200.

35 N. Taouatas, A. J. Heck and S. Mohammed, J. Proteome Res., 2010, 9, 4282-4288.

36 N. Taouatas, M. M. Drugan, A. J. Heck and S. Mohammed, Nat. Methods, 2008, 5, 405-407.

37 S. Gauci, A. O. Helbig, M. Slijper, J. Krijgsveld, A. J. Heck and S. Mohammed, Anal. Chem., 2009, 81, 4493-4501.

38 Y. Marcy, C. Ouverney, E. M. Bik, T. Losekann, N. Ivanova, H. G. Martin, E. Szeto, D. Platt, P. Hugenholtz, D. A. Relman and S. R. Quake, Proc. Natl. Acad. Sci. U. S. A., 2007, 104, 11889-11894.

39 J. J. Agresti, E. Antipov, A. R. Abate, K. Ahn, A. C. Rowat, J. C. Baret, M. Marquez, A. M. Klibanov, A. D. Griffiths and D. A. Weitz, Proc. Natl. Acad. Sci. U. S. A., 2010, 107, 4004-4009.

40 C. P. Jen, J. H. Hsiao and N. A. Maslov, Sensors, 2012, 12, 347-358.

41 C. Ma, R. Fan, H. Ahmad, Q. Shi, B. Comin-Anduix, T. Chodon, R. C. Koya, C. C. Liu, G. A. Kwong, C. G. Radu, A. Ribas and J. R. Heath, Nat. Med., 2011, 17, 738-743.

42 U. Vermesh, O. Vermesh, J. Wang, G. A. Kwong, C. Ma, K. Hwang and J. R. Heath, Angew. Chem., Int. Ed., 2011, 50, 7378-7380.

43 R. S. Annan and S. A. Carr, Anal. Chem., 1996, 68, 34133421.

44 S. A. Beausoleil, M. Jedrychowski, D. Schwartz, J. E. Elias, J. Villén, J. Li, M. A. Cohn, L. C. Cantley and S. P. Gygi, Proc. Natl. Acad. Sci. U. S. A., 2004, 101, 12130-12135.

45 P. Roepstorff and J. Fohlman, Biomed. Mass Spectrom., 1984, 11, 601.

46 B. Paizs and S. Suhai, Mass Spectrom. Rev., 2005, 24, 508548.
47 A. Makarov, E. Denisov, A. Kholomeev, W. Balschun, O. Lange, K. Strupat and S. Horning, Anal. Chem., 2006, 78, 2113-2120.

48 J. Wu, P. Warren, Q. Shakey, E. Sousa, A. Hill, T. E. Ryan and T. He, Proteomics, 2010, 10, 2224-2234.

49 K. Biemann, Methods Enzymol., 1990, 193, 886-887.

50 H. Marx, S. Lemeer, J. E. Schliep, L. Matheron, S. Mohammed, J. Cox, M. Mann, A. J. Heck and B. Kuster, Nat. Biotechnol., 2013, 31, 557-564.

51 S. Di Palma, M. L. Hennrich, A. J. Heck and S. Mohammed, J. Proteomics, 2012, 75, 3791-3813.

52 S. Loroch, Electrophoresis, 2013, 34, 1483-1492.

53 H. Zhou, S. Di Palma, C. Preisinger, M. Peng, A. N. Polat, A. J. Heck and S. Mohammed, J. Proteome Res., 2013, 12, 260-271.

54 D. Winter, J. Seidler, Y. Ziv, Y. Shiloh and W. D. Lehmann, J. Proteome Res., 2009, 8, 418-424.

55 S. B. Ficarro, Y. Zhang, M. J. Carrasco-Alfonso, B. Garg, G. Adelmant, J. T. Webber, C. J. Luckey and J. A. Marto, Mol. Cell. Proteomics, 2011, 10, O111.011064.

56 H. Hahne, F. Pachl, B. Ruprecht, S. K. Maier, S. Klaeger, D. Helm, G. Medard, M. Wilm, S. Lemeer and B. Kuster, Nat. Methods, 2013, 10, 989-991.

57 M. Gilar, P. Olivova, A. E. Daly and J. C. Gebler, J. Sep. Sci., 2005, 28, 1694-1703.

58 F. Zhou, T. W. Sikorski, S. B. Ficarro, J. T. Webber and J. A. Marto, Anal. Chem., 2011, 83, 6996-7005.

59 M. L. Hennrich, V. Groenewold, G. J. Kops, A. J. Heck and S. Mohammed, Anal. Chem., 2011, 83, 7137-7143.

60 R. Ishibashi, K. Mawatari and T. Kitamori, J. Chromatogr. A, 2012, 1238, 152-155.

61 J. Huft, C. A. Haynes and C. L. Hansen, Anal. Chem., 2013, 85, 2999-3005.

62 F. Wang, C. Song, K. Cheng, X. Jiang, M. Ye and H. Zou, Anal. Chem., 2011, 83, 8078-8085.

63 A. M. Palumbo, S. A. Smith, C. L. Kalcic, M. Dantus, P. M. Stemmer and G. E. Reid, Mass Spectrom. Rev., 2011, 30, 600-625.

64 M. W. Pinkse, P. M. Uitto, M. J. Hilhorst, B. Ooms and A. J. Heck, Anal. Chem., 2004, 76, 3935-3943.

65 S. B. Ficarro, M. L. McCleland, P. T. Stukenberg, D. J. Burke, M. M. Ross, J. Shabanowitz, D. F. Hunt and F. M. White, Nat. Biotechnol., 2002, 20, 301-305.

66 J. Rush, A. Moritz, K. A. Lee, A. Guo, V. L. Goss, E. J. Spek, H. Zhang, X. M. Zha, R. D. Polakiewicz and M. J. Comb, Nat. Biotechnol., 2005, 23, 94-101.

67 R. C. Cheung, J. H. Wong and T. B. Ng, Appl. Microbiol. Biotechnol., 2012, 96, 1411-1420.

68 T. S. Nühse, A. Stensballe, O. N. Jensen and S. C. Peck, Mol. Cell. Proteomics, 2003, 2, 1234-1243.

69 J. Villén and S. P. Gygi, Nat. Protoc., 2008, 3, 1630-1638.

70 M. Kokubu, Y. Ishihama, T. Sato, T. Nagasu and Y. Oda, Anal. Chem., 2005, 77, 5144-5154.

71 C. F. Xu, Y. Lu, J. Ma, M. Mohammadi and T. A. Neubert, Mol. Cell. Proteomics, 2005, 4, 809-818.

72 P. Connor and A. McQuillan, Langmuir, 1999, 15, 29162921. 
73 H. Zhou, S. Di Palma, C. Preisinger, M. Peng, A. N. Polat, A. J. R. Heck and S. Mohammed, J. Proteome Res., 2012, 12, 260-271.

74 M. W. Pinkse, S. Mohammed, J. W. Gouw, B. van Breukelen, H. R. Vos and A. J. Heck, J. Proteome Res., 2008, 7, 687-697.

75 M. R. Larsen, T. E. Thingholm, O. N. Jensen, P. Roepstorff and T. J. Jørgensen, Mol. Cell. Proteomics, 2005, 4, 873-886.

76 T. E. Thingholm, O. N. Jensen, P. J. Robinson and M. R. Larsen, Mol. Cell. Proteomics, 2008, 7, 661-671.

77 A. N. Polat, K. Kraiczek, A. J. Heck, R. Raijmakers and S. Mohammed, Anal. Bioanal. Chem., 2012, 404, 2507-2512.

78 R. Raijmakers, C. R. Berkers, A. de Jong, H. Ovaa, A. J. Heck and S. Mohammed, Mol. Cell. Proteomics, 2008, 7, 17551762.

79 R. Raijmakers, A. J. Heck and S. Mohammed, Mol. BioSyst., 2009, 5, 992-1003.

80 L. Beltran and P. R. Cutillas, Amino Acids, 2012, 43, 10091024.

81 K. Engholm-Keller, P. Birck, J. Størling, F. Pociot, T. Mandrup-Poulsen and M. R. Larsen, J. Proteomics, 2012, 75, 5749-5761.

82 J. Pan, B. Naumann-Busch, L. Wang, M. Specht, M. Scholz, K. Trompelt and M. Hippler, J. Proteome Res., 2011, 10, 3830-3839.

83 T. Verano-Braga, V. Schwammle, M. Sylvester, D. G. PassosSilva, A. A. Peluso, G. M. Etelvino, R. A. Santos and P. Roepstorff, J. Proteome Res., 2012, 11, 3370-3381.

84 J. V. Olsen, B. Blagoev, F. Gnad, B. Macek, C. Kumar, P. Mortensen and M. Mann, Cell, 2006, 127, 635-648.

85 P. J. Boersema, L. Y. Foong, V. M. Ding, S. Lemeer, B. van Breukelen, R. Philp, J. Boekhorst, B. Snel, J. den Hertog, A. B. Choo and A. J. Heck, Mol. Cell. Proteomics, 2010, 9, 84-99.

86 S. A. Gerber, J. Rush, O. Stemman, M. W. Kirschner and S. P. Gygi, Proc. Natl. Acad. Sci. U. S. A., 2003, 100, 69406945.

87 N. Ibarrola, D. E. Kalume, M. Gronborg, A. Iwahori and A. Pandey, Anal. Chem., 2003, 75, 6043-6049.

88 G. Zhang and T. A. Neubert, Methods Mol. Biol., 2009, 527, 79-92, xi.

89 B. Blagoev, S. E. Ong, I. Kratchmarova and M. Mann, Nat. Biotechnol., 2004, 22, 1139-1145.

90 A. D. Zoumaro-Djayoon, A. J. Heck and J. Muñoz, Methods, 2012, 56, 268-274.

91 M. Tinti, A. P. Nardozza, E. Ferrari, F. Sacco, S. Corallino, L. Castagnoli and G. Cesareni, New Biotechnol., 2012, 29, 571-577.

92 H. Zhou, M. Ye, J. Dong, E. Corradini, A. Cristobal, A. J. Heck, H. Zou and S. Mohammed, Nat. Protoc., 2013, 8, 461-480.

93 J. Ugelstad, P. C. Mórk, K. H. Kaggerud, T. Ellingsen and A. Berge, Adv. Colloid Interface Sci., 1980, 13, 101-140.

94 R. Raijmakers, C. Berkers, A. de Jong, H. Ovaa, A. Heck and S. Mohammed, Mol. Cell. Proteomics, 2008, 7, 1755-1762.

95 R. Raijmakers, K. Kraiczek, A. de Jong, S. Mohammed and A. Heck, Anal. Chem., 2010, 82, 824-832.
96 O. B. Bleijerveld, P. Wijten, S. Cappadona, E. A. McClellan, A. N. Polat, R. Raijmakers, J. W. Sels, L. Colle, S. Grasso, H. W. van den Toorn, B. van Breukelen, A. Stubbs, G. Pasterkamp, A. J. Heck, I. E. Hoefer and A. Scholten, J. Proteome Res., 2012, 11, 5235-5244.

97 A. Le Nel, J. Krenkova, K. Kleparnik, C. Smadja, M. Taverna, J. L. Viovy and F. Foret, Electrophoresis, 2008, 29, 4944-4947. 98 L. Matheron, S. Clavier, O. Diebate, P. Karoyan, G. Bolbach, D. Guianvarc'h and E. Sachon, J. Am. Soc. Mass Spectrom., 2012, 23, 1981-1990.

99 D. T. McLachlin and B. T. Chait, Anal. Chem., 2003, 75, 6826-6836.

100 H. Nika, E. Nieves, D. H. Hawke and R. H. Angeletti, J. Biomol. Tech., 2013, 24, 132-153.

101 K. R. Willison and D. R. Klug, Curr. Opin. Biotechnol., 2013, 24, 745-751.

102 Y. Xu, K. Jang, T. Yamashita, Y. Tanaka, K. Mawatari and T. Kitamori, Anal. Bioanal. Chem., 2012, 402, 99-107.

103 M. Bantscheff, M. Schirle, G. Sweetman, J. Rick and B. Kuster, Anal. Bioanal. Chem., 2007, 389, 1017-1031.

104 J. Yates, C. Ruse and A. Nakorchevsky, Annu. Rev. Biomed. Eng., 2009, 11, 49-79.

105 M. Bantscheff, S. Lemeer, M. M. Savitski and B. Kuster, Anal. Bioanal. Chem., 2012, 404, 939-965.

106 S. E. Ong, B. Blagoev, I. Kratchmarova, D. B. Kristensen, H. Steen, A. Pandey and M. Mann, Mol. Cell. Proteomics, 2002, 1, 376-386.

107 D. B. McClatchy and J. R. Yates, 3rd, CSH Protoc., 2008, 2008, pdb.prot 4940 .

108 N. Rauniyar, D. B. McClatchy and J. R. Yates, 3rd, Methods, 2013, 61, 260-268.

109 D. Van Hoof, M. W. Pinkse, D. W. Oostwaard, C. L. Mummery, A. J. Heck and J. Krijgsveld, in Nat. Methods, United States, 2007, vol. 4, pp. 677-678.

110 S. E. Ong, I. Kratchmarova and M. Mann, J. Proteome Res., 2003, 2, 173-181.

111 M. Mann, Nat. Rev. Mol. Cell Biol., 2006, 7, 952-958.

112 S. E. Ong, G. Mittler and M. Mann, Nat. Methods, 2004, 1, 119-126.

113 M. Kruger, M. Moser, S. Ussar, I. Thievessen, C. A. Luber, F. Forner, S. Schmidt, S. Zanivan, R. Fassler and M. Mann, Cell, 2008, 134, 353-364.

114 S. E. Ong and M. Mann, Nat. Chem. Biol., 2005, 1, 252-262. 115 P. L. Ross, Y. N. Huang, J. N. Marchese, B. Williamson, K. Parker, S. Hattan, N. Khainovski, S. Pillai, S. Dey, S. Daniels, S. Purkayastha, P. Juhasz, S. Martin, M. Bartlet-Jones, F. He, A. Jacobson and D. J. Pappin, Mol. Cell. Proteomics, 2004, 3, 1154-1169.

116 A. Thompson, J. Schäfer, K. Kuhn, S. Kienle, J. Schwarz, G. Schmidt, T. Neumann, R. Johnstone, A. K. Mohammed and C. Hamon, Anal. Chem., 2003, 75, 1895-1904.

117 L. Dayon, A. Hainard, V. Licker, N. Turck, K. Kuhn, D. F. Hochstrasser, P. R. Burkhard and J. C. Sanchez, Anal. Chem., 2008, 80, 2921-2931.

118 S. P. Gygi, B. Rist, S. A. Gerber, F. Turecek, M. H. Gelb and R. Aebersold, Nat. Biotechnol., 1999, 17, 994-999. 
119 J.-L. Hsu, S.-Y. Huang, N.-H. Chow and S.-H. Chen, Anal. Chem., 2003, 75, 6843-6852.

120 J. L. Hsu, S. Y. Huang and S. H. Chen, Electrophoresis, 2006, 27, 3652-3660.

121 P. J. Boersema, R. Raijmakers, S. Lemeer, S. Mohammed and A. J. Heck, Nat. Protoc., 2009, 4, 484-494.

122 S. Di Palma, R. Raijmakers, A. J. Heck and S. Mohammed, Anal. Chem., 2011, 83, 8352-8356.

123 A. F. Altelaar, C. K. Frese, C. Preisinger, M. L. Hennrich, A. W. Schram, H. T. Timmers, A. J. Heck and S. Mohammed, J. Proteomics, 2013, 88, 14-26.

124 R. Zhang, C. S. Sioma, R. A. Thompson, L. Xiong and F. E. Regnier, Anal. Chem., 2002, 74, 3662-3669.

125 P. J. Boersema, R. Raijmakers, S. Lemeer, S. Mohammed and A. J. R. Heck, Nat. Protoc., 2009, 4, 484-494.

126 W. M. Old, K. Meyer-Arendt, L. Aveline-Wolf, K. G. Pierce, A. Mendoza, J. R. Sevinsky, K. A. Resing and N. G. Ahn, Mol. Cell. Proteomics, 2005, 4, 1487-1502.

127 J. M. Asara, H. R. Christofk, L. M. Freimark and L. C. Cantley, Proteomics, 2008, 8, 994-999.

128 N. M. Griffin, J. Yu, F. Long, P. Oh, S. Shore, Y. Li, J. A. Koziol and J. E. Schnitzer, Nat. Biotechnol., 2010, 28, 83-89.

129 Y. Zhang, Z. Wen, M. P. Washburn and L. Florens, Anal. Chem., 2009, 81, 6317-6326.

130 H. Choi, D. Fermin and A. I. Nesvizhskii, Mol. Cell. Proteomics, 2008, 7, 2373-2385.

131 D. A. Megger, L. L. Pott, M. Ahrens, J. Padden, T. Bracht, K. Kuhlmann, M. Eisenacher, H. E. Meyer and B. Sitek, Biochim. Biophys. Acta, 2014, 1844, 967-976.

132 D. S. Kirkpatrick, S. A. Gerber and S. P. Gygi, Methods, 2005, 35, 265-273.

133 R. J. Beynon, M. K. Doherty, J. M. Pratt and S. J. Gaskell, Nat. Methods, 2005, 2, 587-589.

134 V. Brun, A. Dupuis, A. Adrait, M. Marcellin, D. Thomas, M. Court, F. Vandenesch and J. Garin, Mol. Cell. Proteomics, 2007, 6, 2139-2149.

135 S. Hanke, H. Besir, D. Oesterhelt and M. Mann, J. Proteome Res., 2008, 7, 1118-1130.

136 S. Singh, M. Springer, J. Steen, M. W. Kirschner and H. Steen, J. Proteome Res., 2009, 8, 2201-2210.

137 C.-Y. Chang, P. Picotti, R. Hüttenhain, V. HeinzelmannSchwarz, M. Jovanovic, R. Aebersold and O. Vitek, Mol. Cell. Proteomics, 2012, 11, DOI: 10.1074/mcp.M111.014662.

138 R. Aebersold, A. L. Burlingame and R. A. Bradshaw, in Mol. Cell Proteomics, United States, 2013, vol. 12, pp. 23812382.

139 M. Jovanovic, L. Reiter, A. Clark, M. Weiss, P. Picotti, H. Rehrauer, A. Frei, L. J. Neukomm, E. Kaufman, B. Wollscheid, M. J. Simard, E. A. Miska, R. Aebersold, A. P. Gerber and M. O. Hengartner, Genome Res., 2012, 22, 1360-1371.

140 R. Raijmakers, A. Heck and S. Mohammed, Mol. BioSyst., 2009, 5, 992-1003.

141 J. E. Purvis and G. Lahav, Cell, 2013, 152, 945-956.

142 D. Bakstad, A. Adamson, D. G. Spiller and M. R. White, Curr. Opin. Biotechnol., 2012, 23, 103-109.
143 M. Diehn, R. W. Cho, N. A. Lobo, T. Kalisky, M. J. Dorie, A. N. Kulp, D. Qian, J. S. Lam, L. E. Ailles, M. Wong, B. Joshua, M. J. Kaplan, I. Wapnir, F. M. Dirbas, G. Somlo, C. Garberoglio, B. Paz, J. Shen, S. K. Lau, S. R. Quake, J. M. Brown, I. L. Weissman and M. F. Clarke, Nature, 2009, 458, 780-783.

144 X. Ma, L. H. Zhang, L. R. Wang, X. Xue, J. H. Sun, Y. Wu, G. Zou, X. Wu, P. C. Wang, W. G. Wamer, J. J. Yin, K. Zheng and X. J. Liang, ACS Nano, 2012, 6, 10486-10496. 145 D. Majumdar, K. H. Jung, H. Zhang, S. Nannapaneni, X. Wang, A. R. Amin, Z. Chen, Z. G. Chen and D. M. Shin, Cancer Prev. Res., 2014, 7, 65-73.

146 E. K. Chow and D. Ho, Sci. Transl. Med., 2013, 5, 216 rv214. 147 H. Lu, L. Y. Koo, W. M. Wang, D. A. Lauffenburger, L. G. Griffith and K. F. Jensen, Anal. Chem., 2004, 76, 5257-5264.

148 J. H. Kang, Y. C. Kim and J. K. Park, Lab Chip, 2008, 8, 176178.

149 P. J. Hung, P. J. Lee, P. Sabounchi, R. Lin and L. P. Lee, Biotechnol. Bioeng., 2005, 89, 1-8.

150 K. R. King, S. Wang, A. Jayaraman, M. L. Yarmush and M. Toner, Lab Chip, 2008, 8, 107-116.

151 R. Gomez-Sjoberg, A. A. Leyrat, D. M. Pirone, C. S. Chen and S. R. Quake, Anal. Chem., 2007, 79, 8557-8563.

152 S. Mohammed, K. Kraiczek, M. Pinkse, S. Lemeer, J. Benschop and A. Heck, J. Proteome Res., 2008, 7, 15651571.

153 J. Srbek, J. Eickhoff, U. Effelsberg, K. Kraiczek, T. van de Goor and P. Coufal, J. Sep. Sci., 2007, 30, 20462052.

154 C. Zhao, Z. Wu, G. Xue, J. Wang, Y. Zhao, Z. Xu, D. Lin, G. Herbert, Y. Chang, K. Cai and G. Xu, J. Chromatogr. A, 2011, 1218, 3669-3674.

155 A. Manz, N. Graber and H. M. Widmer, Sens. Actuators, B, 1990, 1, 244-248.

156 T. Thorsen, S. J. Maerkl and S. R. Quake, Science, 2002, 298, 580-584.

157 V. Lecault, A. K. White, A. Singhal and C. L. Hansen, Curr. Opin. Chem. Biol., 2012, 16, 381-390.

158 W. Wei, Y. S. Shin, C. Ma, J. Wang, M. Elitas, R. Fan and J. R. Heath, Genome Med., 2013, 5, 75.

159 J. M. de Oliveira and L. H. de Graaff, Appl. Microbiol. Biotechnol., 2011, 89, 225-237.

160 R. A. Laursen, Eur. J. Biochem., 1971, 20, 89-102.

161 P. H. O'Farrell, J. Biol. Chem., 1975, 250, 4007-4021.

162 M. Karas and F. Hillenkamp, Anal. Chem., 1988, 60, 22992301.

163 J. B. Fenn, M. Mann, C. K. Meng, S. F. Wong and C. M. Whitehouse, Science, 1989, 246, 64-71.

164 A. Manz, D. J. Harrison, E. M. J. Verpoorte, J. C. Fettinger, A. Paulus, H. Lüdi and H. M. Widmer, J. Chromatogr. A, 1992, 593, 253-258.

165 M. Mann and M. Wilm, Anal. Chem., 1994, 66, 4390-4399.

166 J. A. Loo, Mass Spectrom. Rev., 1997, 16, 1-23.

167 M. Bantscheff, M. Boesche, D. Eberhard, T. Matthieson, G. Sweetman and B. Kuster, Mol. Cell. Proteomics, 2008, 7, 1702-1713. 
168 S. Wiese, K. A. Reidegeld, H. E. Meyer and B. Warscheid, Proteomics, 2007, 7, 340-350.

169 S. Di Palma, D. Stange, M. van de Wetering, H. Clevers, A. J. Heck and S. Mohammed, J. Proteome Res., 2011, 10, 3814-3819.

170 K. T. Rigbolt, T. A. Prokhorova, V. Akimov, J. Henningsen, P. T. Johansen, I. Kratchmarova, M. Kassem, M. Mann, J. V. Olsen and B. Blagoev, Sci. Signaling, 2011, 4, rs3.

171 D. Ishii and T. Takeuchi, TrAC, Trends Anal. Chem., 1990, 9, 152-157.

172 A. Jovic, B. Howell and S. Takayama, Microfluid. Nanofluid., 2009, 6, 717-729.

173 K. K. Sanford, W. R. Earle and G. D. Likely, J. Natl. Cancer Inst., 1948, 9, 229-246.

174 S. C. Terry, J. H. Jerman and J. B. Angell, IEEE Trans. Electron Devices, 1979, 26, 1880-1886.
175 D. J. Harrison, A. Manz, Z. Fan, H. Luedi and H. M. Widmer, Anal. Chem., 1992, 64, 1926-1932.

176 D. C. Duffy, J. C. McDonald, O. J. A. Schueller and G. M. Whitesides, Anal. Chem., 1998, 70, 4974-4984.

177 J. Olofsson, H. Bridle, J. Sinclair, D. Granfeldt, E. Sahlin and O. Orwar, Proc. Natl. Acad. Sci. U. S. A., 2005, 102, 8097-8102.

178 Y. Lee, E. K. Lee, Y. W. Cho, T. Matsui, I. C. Kang, T. S. Kim and M. H. Han, Proteomics, 2003, 3, 2289-2304.

179 J. Skommer, D. McGuinness and D. Wlodkowic, Biotech. Histochem., 2011, 86, 174-180.

180 N. J. Panaro, P. K. Yuen, T. Sakazume, P. Fortina, L. J. Kricka and P. Wilding, Clin. Chem., 2000, 46, 18511853.

181 A. G. Hadd, D. E. Raymond, J. W. Halliwell, S. C. Jacobson and J. M. Ramsey, Anal. Chem., 1997, 69, 3407-3412. 